\title{
Assessment of Gold Mining Impact on the Vegetation of Itagunmodi-Igun Drainage Basin, Southwestern Nigeria from 1972-2011: A Remote Sensing
}

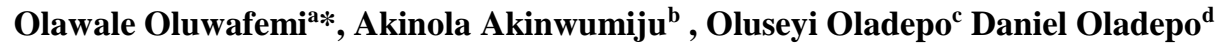 \\ a , Spatially Integrated Social Science Program, University of Toledo, $\mathrm{OH}$, United States of America, America, \\ Olawale.Oluwafemi@ rockets.utoledo.edu \\ ${ }^{b}$ Federal University of Technology, Akure, Nigeria, asakinwumiju@futa.edu.ng \\ ${ }^{c}$ African Regional Institute for Geospatial Information Science and Technology, OAU, Ile-Ife, Nigeria, oluseyioladepo@gmail.com \\ ${ }^{d}$,Bowling Green State University, Bowling Green, OH, United States, danieloladepo@gmail.com \\ * Corresponding author
}

\begin{abstract}
A GIS-based Normalized Differential Vegetation Index (NDVI) was analyzed using space-based data between 1972 and 2011 as Input data. The result of the NDVI using Landsat 7 ETM+ shows clearly that the values range from 0.19 to -0.31 . Mountains and highlands of the Itagunmodi-Igun area revealed stressed vegetation cover between 0.11 to -0.31. The NDVI was also performed on Landsat imageries of four different epoch: 1972, 1986, 2000, and 2010. Results showed that vegetation index ranged from -0.105 to $0.033,-0.25$ to $0.480,-0.313$ to 0.19 and -0.29 to 0.5 in 1972,1986 , 2000 and 2010 respectively. The analysis revealed that the study area experienced an increase in biomass between 1972 and 1986 but with some areas experiencing outright disappearance of vegetation as indicated by the lower bands of index values in $1972(-0.105)$ and $1986(-0.25)$. The result showed that the Basin experienced a rapid and significant increase in biomass between 2000 and 2010, as indicated by the lower bands of index values in $2000(-0.291)$ and $2010(0.5)$. The results of the NDVI in 1972 ranged from -0.105 to 0.033 while NDVI in 1986 ranged from -0.25 to 0.480 which indicated a significant increase in the vegetation index. The results of the NDVI in 2000 ranged from 0.291 to 0.5 also indicated a significant increase in the vegetation index. The study concluded that artisanal mining could cause land and vegetation degradation with consequent loss of biodiversity, ecological modification.
\end{abstract}

Keywords: Landscape, Artisanal, Mining, Gold deposit, Nigeria

\section{Introduction}

Mining occurs when there is an extraction of minerals or other geological materials from the earth's crust; which forms the mineralized package of economic interest to the miner [Oluwafemi, 2018, Oyinloye, 1992]. However, mining activities also impact negatively on the waters, landscape, vegetation and the atmosphere at the mine sites [Oyinloye, 1992; Ako et al., 2013]. Gold with the chemical symbol $(\mathrm{Au})$ coined from the Latin word aurum falls into the categories of transition metals. It can occur as nuggets or grains, in rocks veins or alluvial deposits. According to Hawas et al. (2013), environmental consequences of gold mining can be devastating, particularly in fragile tropical ecosystems because toxic substances like cyanide and mercury are usually involved in its extraction. Several studies exist on the impact of mining on the environment both at micro and macro levels (Schueler, et al., 2011; Oyinloye, 1996; Ako et al., 2014; Hawas et al., 2013). For instance, Sima, et al. (2008) observed that both natural and socioeconomic activities are impacted qualitatively and quantitatively as a result of mining activities in the Certej River Catchment, Western Carpathians, Romania. Few studies, (Hawas et al., 2013; Oyinloye, 1996; Ako et al., 2014) especially in the field of Geoinformatics, have examined mining and it's impact on the geomorphology and social well being in a comparative manner. Koruyan et al. (2012) in their study of Remote Sensing in management of mining land and proximate habitat, used satellite images taken in the summer of 2001 to 2009 to determine landuse and landcover at Mulga province in western Turkey. Advanced Spaced Thermal Emission Radar (ASTER) and Landsat images used include $15 \mathrm{~m}$ and $30 \mathrm{~m}$ resolution in order to use a consistent set of data. The study revealed that the extent of marble quarries expansion covered 36,390 hectares and revealed clearly the rate of quarry expansion grew from $0.54 \%$ in 2001 to $2.89 \%$ in 2009 over the entire study area. The study also confirmed that the vegetation around quarries was influenced by mining operations, natural vegetation reduced drastically while quarries covered larger land areas. The study however, recommended that mining sites should be closely monitored at both micro and macro scales using geospatial techniques. Gold in Nigeria is found in alluvial deposits and primary deposit in rock veins from several parts of supracrustal (schist) belts in the northwest and southwest of Nigeria (Mesubi, et al. 1999). In fact, Nigeria is one of the countries in Africa producing gold in large quantities preceded by Ghana and Tanzania (Schueler et al., 2011). It is interesting to know that the most resourceful gold occurrences in Nigeria are found in the Maru, Anka, Malele, Tsohon Birin Gwari-Kwaga, Gurma, Bin Yauri, Luku, Okolom-Dogondaji, Itagunmodi, Igun and Iperindo 
areas, all associated with the schist belts of northwest and southwest Nigeria.

Traditionally, the effects of gold mining have long attracted the interest of geomorphologists both in terms of their landforms, vegetation alteration and biodiversity response to change. An important goal in mapping and assessment process is to extract hidden relationships and effects between some variables. In recent year, there has also been a wider growing recognition of human impacts on the earth's global systems (Adediji and Oluwafemi, 2007). Surface mining, for example, removes vegetation and soils, interrupts ecosystem service flows, and results in inevitable and often permanent farmland loss. Gold mining activities also frequently result in toxic waste that causes water pollution and health problems. Studies have also shown that mining at both small and large scale has great impact on vegetation and soil, land use, livelihood foundations and geomorphology of African countries. Monitoring vegetation from space can provide relevant information quickly, repeatedly and at regular intervals of time. Since 1970s, satellite remote sensing have been commonly used for understanding the cumulative influence of man on landscape and vegetation (Wickware and Howarth, 1981). Kushwaha et al. (2011) used remote sensing data in mapping the forests Kaziranga National Park for determining habitat changes that occurred after the flood event. Gautam and Chenniah (1985) analysed Tripura vegetation using Landsat imagery data. In Nigeria, Mesubi et al. (1999) and Ako et al. (2014) studies on extraction of gold from Igun gold ore deposit in Atakumosa West Local Government Area, Osun state, and environmental impact of artisanal gold mining in Luku, Niger state respectively. These authors also affirmed serious effect of artisanal gold mining on vegetation in this part of the world. Hence, based on the above scenario, the present study examines and analyses effects of artisanal gold mining on the vegetation within the Itagunmodi and Igun Area, Atakumosa West Local Government Area, Southwestern Nigeria with a view of providing a framework for the monitoring and responding to vegetation degradation. The Itagunmodi-Igun Drainage Basin is located within the Ilesa Schist Belt in Southwestern Nigeria between Latitude $7025^{\prime} 043^{\prime}$ ' $\mathrm{N}$ to $7045^{\prime}$ 032 ' 'N north of the Equator and Longitude $4035^{\prime} 023$ ' $\mathrm{E}$ to $4055^{\prime} 045^{\prime}$ ' $E$ east of the Greenwich Meridian. (Figure 1.1) Itagunmodi-Igun is located in Atakumosa West local government area of Osun State and bounded on the west by Atakumosa East, Ilesa East and West LGAs; on the north by Ede North and Ede South LGAs, Boripe and Osogbo LGAs; on the south by Ife South LGA and Ile Oluji/Okeigbo LGA (Figure 1.1). The Itagunmodi-Igun drainage basin occupies an area of 74,031,443 km2 within mining sites in close areas like Faforiji, Epe, Ibodi, Iwara Odo, Iperindo, Atorin and Iyemogun (Oluwafemi, 2018). Ilesa Schist Belt has a north-south length of approximately $200 \mathrm{~km}$ and reaches its maximum width of approximately $60 \mathrm{~km}$ in the south.

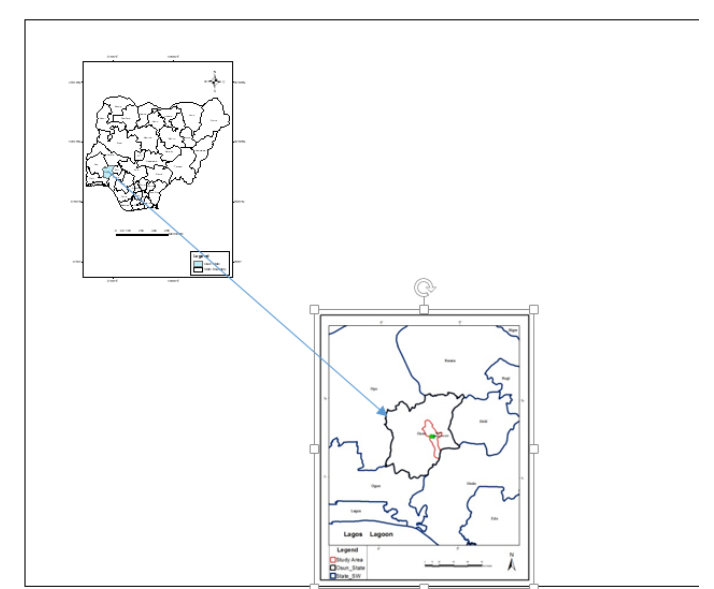

Figure 1: Osun state showing Itagunmodi and Igun Drainage Basin Area, Atakumosa, LGA.

Hence, it consists of two structural units with contrasting lithology, separated by the NNE-trending Ife fault zone (Oke et al., 2013). The western unit (Figure 1.2) (which is the focus of this study) consists of amphibolite, amphibole schist, and pelitic schist with much intimately associated trondjemitic granite, gneiss, and pegmatite (Oke et al., 2013; Oyinloye, 2011).

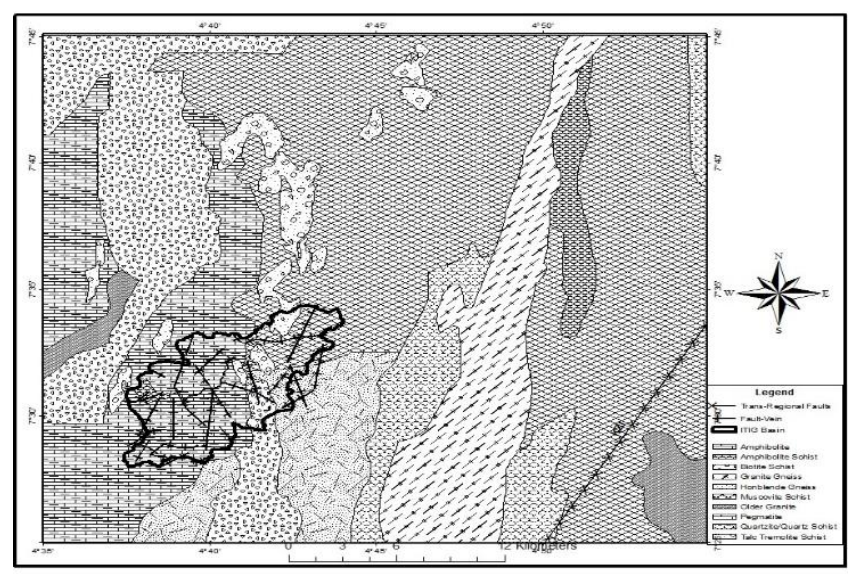

Figure 1.2: Geology of Ilesa Schist Belt Showing the Study Area Source: Modified after, Oyinloye, 1992

The metamorphism is mainly evident in the amphibolite facies, but locally in greenschist facies (Oke et al., 2013; Oyinloye, 2011). At the eastern axis of the fault (the Iperindo catchment) quartzite is dominant, occurring together with quartz schist, quartzo-felspathic-gneiss, and minor iron-rich schist (Oke et al., 2013; Oyinloye, 2011). The deciduous rainforest of the study area can be sub-divided into three types. These include the disturbed rainforest, the light forest, and the patches of thick forest. The disturbed rainforest is the anthropogenically impacted rainforest with many randomly distributed open spaces as a result of human activities such as agriculture, mining, lumbering, and fuelwood harvesting. The light forest is an emerging forest at the stage of secondary succession that is common on the slightly weathered rocks. The patches of thick forest are the few natural rainforests of the Southwestern Nigeria that are relatively protected from 
encroachment. These include the forest reserves and traditionally preserved forests that are consecrated to some traditional religions and festivals in Yoruba Land (Orimoogunje, Oyinloye, and Momodou, 2009; Oluwafemi, 2018). The wet season in the area is normally characterized by two maximal rainfalls with peaks occurring in July and September or October. The rainfall record of Itagunmodi between 1975-2000 indicates that annual rainfall varies from $923 \mathrm{~mm}-2116 \mathrm{~mm}$ with a mean of $1389.29 \mathrm{~mm}$, and the temperature is generally high (Olayiwola and Aguda, 2009). The range of temperature during the dry season especially between December and April is between 210 and $30 \mathrm{oC}$.Also, as observed by Olayiwola and Aguda (2009) the mean daily minimum and maximum temperature in the area is $20 \mathrm{oC}$ and $33 \mathrm{oC}$ respectively.

\section{Materials and Method}

The data used in the study included primary and secondary data: The primary data involves the field survey and observation of all the notable mining sites. Focus Group Discussions (FGDs) were held with people who had lived in Itagunmodi and Igun for over 15 years, as well as the artisanal gold miners as a means of eliciting data which involves all the working practices and methods of mining used by the artisanal gold miners within the study area. The geographic locations of goldfields visited by the author within the study area were also determined and mapped. These were obtained by capturing geographical coordinates (Latitude and Longitude) of each location using Garmin Handheld Global Positioning System (GPS). The secondary data includes Itagunmodi-Igun Drainage Basin map (also known as the catchment boundary map) was produced using Digital Elevation Model (2013 SRTM's DEM) in a GIS environment. The road and settlement features were also integrated with the catchment boundary features to generate a field survey guide map. Also, Geological and Geomorphological Information (Lineament, Soil, Geological, Geomorphological and Hydrological maps) 2011 and 2013 were obtained from the Nigerian Geological Survey Agency (NGSA) and relevant literature. Satellite imagery of Landsat1972, 1986, 2000, 2010, and 2011 was also downloaded from the United States Geological Survey (USGS) official website. The data and their sources are presented in Table 2.1 .
Table 2.1: Data Sources

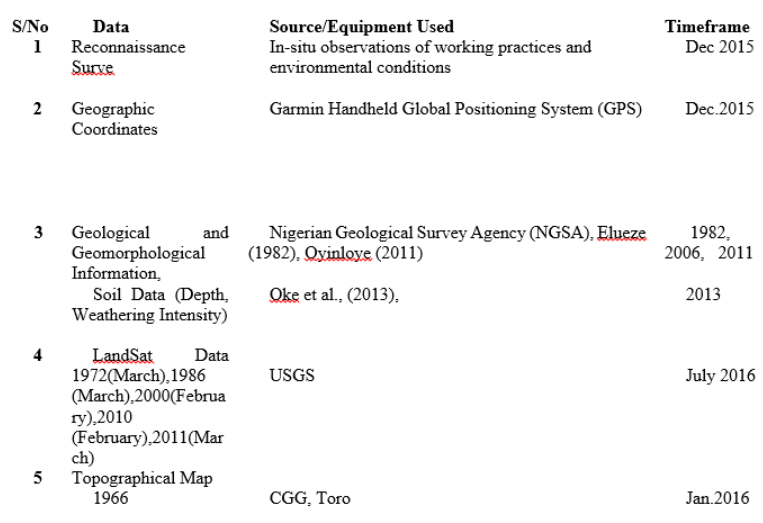

\subsection{Normalized Differential Vegetation Index}

These imageries (Landsat Imagery 1972, 1986, 2000, 2010, and 2011) were used to carry out Normalized Differential Vegetation Index Analysis (NDVI) of the study area. This analysis was done by calculating visible and near-infrared light reflected by vegetation using ERDAS IMAGINE 2014. Healthy vegetation absorbs most of the incoming visible light and reflects a small portion (about 25\%) of the near-infrared (NIR) light, but a low portion in the red band (RED). Stressed or sparse vegetation reflects more visible light and less NIR light.

Calculation of NDVI for a given pixel always results in a number that ranges from minus one $(-1)$ to plus one $(+1)$ : Bare soils give a value close to zero and very dense green vegetation have values close to $+1(0.8-0.9)$. The NDVI technique was adopted to assess the possible effect of artisanal gold mining on vegetation within the drainage basin for the year 2011 .

\section{Results and Discussion}

\subsection{Artisanal Gold Mining In Itagunmodi-Igun Drainage Basin}

The condition of the immediate environment of the six gold mine sites that were visited during the reconnaissance and field study namely Asegbon 1, Asegbon 2, Itagunmodi 1, Itagunmodi 2, Itagunmodi 3, and Igun 1 (Abandoned gold mining site) Table 1.1

The area of the mining sites ranges from 50-100m 2 and the site condition is poorly drained with clayed soil (Oluwafemi, 2018).

$\begin{array}{cccllll}\begin{array}{c}\text { Serial } \\ \text { No }\end{array} & \text { Longitude } & \text { Latitude } & \text { Mining Site } & \text { Site Condition } & \text { Area }\left(\mathbf{m}^{\mathbf{2}}\right) \\ 1 & 4.652256 & 7.530031 & \text { Itagunmodi 1 } & \text { Poorly drained clayed soil } & 60 \\ 2 & 4.660025 & 7.528287 & \text { Itagunmodi 2 } & \text { Poorly drained clayed soil } & 75 \\ 3 & 4.654952 & 7.526067 & \text { Itagunmodi 3 } & \text { Poorly drained clayed soil } & 50 \\ 4 & 4.660183 & 7.512909 & \text { Asegbon 1 } & \text { Poorly drained clayed soil } & 65 \\ 5 & 4.655427 & 7.510531 & \text { Asegbon 2 } & \text { Poorly drained clayed soil } & 80 \\ 6 & 4.675878 & 7.528128 & \text { Igun 1 } & \text { Poorly drained clayed soil } & 100\end{array}$

Source: Oluwafemi, 2018

3.2 Description of Observed Effect on Vegetation of Itagunmodi-Igun Drainage Basin

The Normalized Differential Vegetation Index (NDVI) was analyzed using Landsat 7 ETM+ NDVI values range from 0.19 to -0.31 . The value 0.1 (high) represents pixels covered by a substantial proportion of healthy vegetation while -0.3 (low) represents pixels covered by non- 
vegetated surfaces including water, anthropogenic features, bare soil, and unhealthy or stressed vegetation (Figure 3).

The NDVI map of the study area was overlaid on the drainage networks and settlement locations thus revealing clearly the effects of artisanal gold mining on the vegetation of the study area. The effect on the vegetation varies from Bowale community (lowland) to Iwikun community (highland). The variation in vegetation patterns within the drainage basin can be attributable to activities like mining, settlement pattern, farming, bush burning, and rock outcrops. Mountains and highlands of Itagunmodi-Igun area reveal stressed vegetation cover between 0.11 to -0.31 . However, this can be better explained due to the little rock outcrops at the peak of the mountains and weathering activities at the foot of the mountain and highlands which in turn affect vegetation index in the study area. The NDVI values of the study area also reveal clearly that the vegetation has been impacted along the stream-heads and river channels; these impacted areas are due to mining of Sediment-Hosted Disseminated Gold Deposits (SHDGD). These impacted areas are clearly revealed in Itagunmodi, Igun, Bowale and Itikan communities

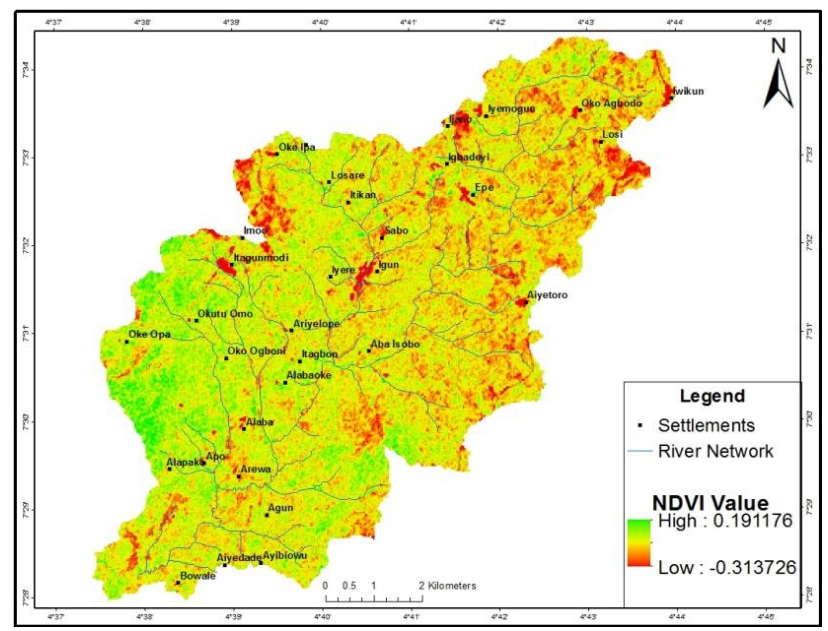

Figure 3.1: Normalized Differential Vegetation Index (NDVI) (2011) of Itagunmodi-Igun drainage basin.

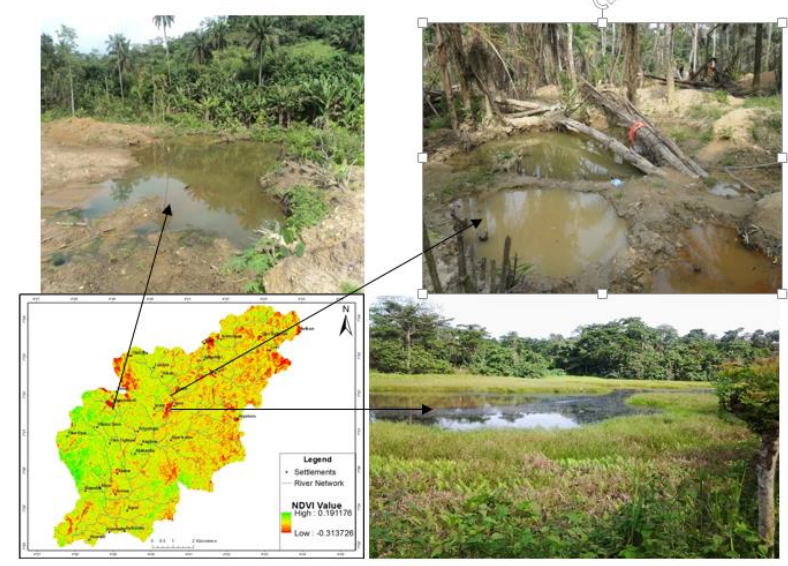

Figure 3.2: Effects of Artisanal Gold mining on the Vegetation of Gold Mining Sites within Itagunmodi-Igun Drainage Basin

\subsection{NDVI between 1972-2010 Itagunmodi-Igun}

\section{Drainage Basin}

The NDVI maps are presented in figure 3.3. The result indicates that vegetation index ranged from -0.105882 to $0.0337079,-0.25$ to $0.480916,-0.313726$ to 0.191176 and -0.291139 to 0.5 in $1972,1986,2000$ and 2010 respectively. The result of the analysis indicates that the study area experienced an increase in biomass between 1972 and 1986 but with some areas experiencing outright disappearance of vegetation as indicated by the lower bands of index values in $1972(-0.105882)$ and 1986 ($0.25)$. This incidence might probably be attributed to artisanal mining activities within the study area. The result showed that the basin experienced a rapid and significant increase in biomass between 2000 and 2010, as indicated by the lower bands of index values in $2000(-0.291139)$ and $2010(0.5)$ probably as a result of public sensitization and awareness of the detrimental impacts of bush burning as well as deforestation.
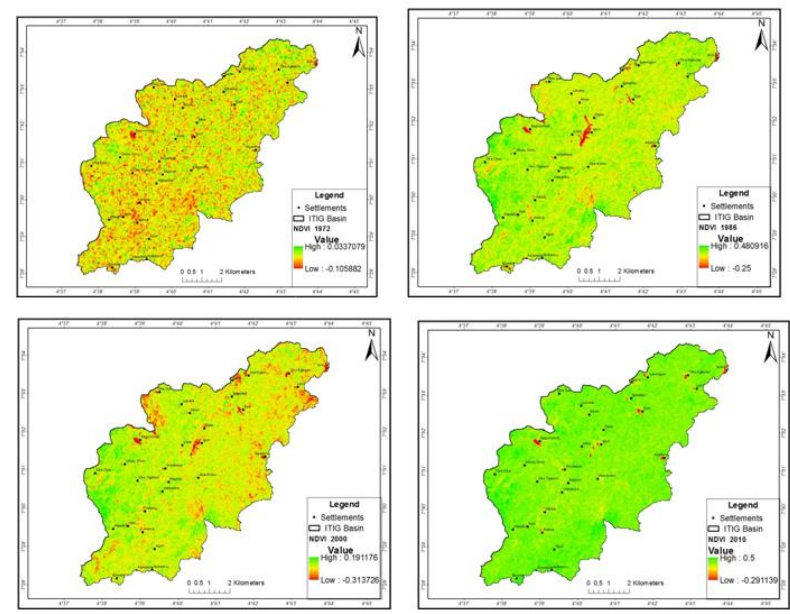

Figure 3.3: NDVI between 1972-2010 within ItagunmodiIgun Drainage Basin.

\subsection{Effects of mining on the vegetation within the study area}

The Normalized Differential Vegetation Index (NDVI) of the drainage basin reveals clearly that vegetations are impacted along the stream-heads and river channels; these impacted areas are due to mining of Sediment-Hosted Disseminated Gold Deposits (SHDGD). These impacted areas are revealed in Itagunmodi, Igun, Bowale and Itikan communities. The results of the NDVI in 1972 ranged from -0.105 to 0.033 while NDVI in 1986 ranged from 0.25 to 0.480 which indicated significant increase in the vegetation pattern. The results of the NDVI in 2000 ranged from 0.291 to 0.5 also indicated significant increase in the vegetation pattern. When you compared the NDVI value from 1972-1986 to 2000-2010 the study revealed that the basin gained an increase in the overall vegetation pattern

\subsection{Conclusion and Recommendations}

This study shows the significant impact of artisanal gold mining in Itagunmodi-Igun drainage basin, Southwestern, 
Nigeria, and has negative effects on the miners, the community, and ultimately the environment. The study identifies that semi-mechanized mining was practiced for almost three decades in the area. It was obvious that miners practiced crude method of mining which is a clear departure from international best practices. The result shows that human-induced activities particularly sediment-hosted disseminated gold mining impacted on the weathering intensity of the underlying bedrocks of the area. The host communities are also at receiving end of the environmental damage caused by the mining activities. The forest ecosystem is adversely affected by the loss of biodiversity in the sites visited; the water receives leachates of heavy metals which make it unfit for human use or even for agriculture, and the terrain is deformed. The study concluded that mining both artisanal, semi-mechanized, and mechanized could trigger extensive terrain deformation with consequent loss of biodiversity, ecological modification, and increase in sediment delivery ratio and drainage obstruction within the Basin. The study recommended that the government should implement more efficient and better practices to be used by the artisanal miners this will go a long way to prevent miners from been exposed to the deadly diseases that are associated with gold mining using rudimentary tools. The study further recommended that the government should take into cognizance the spatial peculiarities of the gold mining sites in Nigeria using the latest technologies like Unmanned Aerial Vehicles (UAV), LIDAR, and InSAR by providing soft research grants in such areas and efforts should be built towards land reclamation.

\section{References}

Adediji, A.A. and Oluwafemi, O.A. (2007). Grain Size Characteristics of Overbank Deposits of Some Floodplain in Opa Reservoir Basin, SW Nigeria, International Journal of Environmental Hydrology, 15:3-4

Ajeigbe, O.M., Adeniran, O.J. and Babalola, O.A. (2014). Mineral Prospecting Potentials of Osun State, European Journal of Business and Management, $6(2): 1-4$

Ako, T.A., Onoduku, U.S., Adamu, I. A., Ali, S. E., Mamodu A. and Ibrahim A. T. (2014). Environmental Impact of Artisanal Gold Mining in Luku, Minna, Niger State, North Central Nigeria, Journal of Geosciences and Geomatics, 2 (1): $1-10$

Gautam and Chenniah (1985). Land-use and Land-cover mapping and change detection in Tripura using satellite LANDSAT data, International Journal of Remote Sensing, 6:(3) 1-3

Hawas, F., Hamidullah T. and Fayaz, A. (2013). The Effect of Mining on Geomorphology, Impact Assessment (International Association for Impact Assessment, IAIA), 16 (20): 190-200

Koruyan, K., Deliormanli, A. H., Karaca, Z., Momayez, M., Lu, H. and Yalcin, E. (2012). Remote
Sensing in Management of Mining Land and Proximate Habitat, Journal of The Southern African Institute of Mining and Metallurgy, 11(2):1-6

Kushwaha, S.P.S., Nandy, S., Ahmad, M. and Agarwal, R.(2011).Forest Ecosystem Dynamics Assessment and Predictive Modelling in Eastern Himalaya, Proceeding of ISPRS, Vol 22 (3): 1-6

Mesubi, M.A., Adekola, F.A., Bello, A.A., Adekeye, J.D. and Bale, R.B. (1999). Extraction of Gold From Igun Gold Ore Deposit in Atakumosa Local Government Area, Osun State, Nigeria, Nigerian Journal and Applied Science, 14 (2):1-7

Oke, S. A., Mijani, M.N. and Adeyemo O.M.(2013): Influence of Bedrock Weathering On the Shallow Ground Water System Around Felsic Metasediment and Amphibolites of The Ilesa Schist Belt, Transnational Journal of Science and Technolog y, 3 (1):1-9

Olayiwola and Aguda, A.S. (2009). Hierrachy of Service Centre in Ijesaland, Nigeria, Journal of Geography and Regional Planning, 2 (5):131-143

Oluwafemi, O.A. (2018). Effects of Artisanal Gold Mining on the Landscape of Itagunmodi-Igun Drainage Basin, Southwestern Nigeria, An Unpublished M.Sc. Thesis Submitted to the Postgraduate School, Nigerian Defence Academy, Kaduna, Nigeria, 2-12.

Orimoogunje, O. O. I., Oyinloye, R. O. and Momodou, S. (2009). Geospatial Mapping of Wetlands Potential in Ilesa, Southwestern Nigeria, FIG Working Week, Surveyors Key Role in Accelerated development, Eilat, Israel, 4-9

Oyinloye, A.O. (1992). Genesis of the Iperindo Gold Deposit, Ilesa Schist Belt, South-western Nigeria, Unpublished Master Dissertation of the University of Wales, Cardiff, U.K, 6-9

Oyinloye, A.O. and Odeyemi, S.B. (2001). The Geochemistry, Ectonic Setting and Origin of the Massive Melanocratic Amphibolites in Ilesa Schist Belt, South-western Nigeria. GJPAS,7(1):55-66.

Oyinloye, A.O. (2011). Geology and Geotectonic Setting of the Basement Complex Rocks in Southwestern Nigeria: Implications on Provenance and Evolution, Earth and Environmental Sciences, Croatia 3 (6): $1-7$

Schueler, V., Kuemmerle, T. and Schroder, H. (2011). Impact of Surface Gold Mining on Landuse Systems in Western Ghana, Royal Swedish Academy of Science, 40:528-535. 
Sima, M., Zobrist, J. Senila, M. Level, E.,

Abraham, B. and Balteanu, D.(2008).

Environmetal Pollution By Mining

Activities- A Case Study In the Cris Alb

Valley,Western Carpathians, Romania,

Proceedings of the Swiss- Romanian

Research Programme on Environmental Science

and Technology, 1-12

Wickware, A. and Howarth, D. (1981). Change detection in the Peace-Athabasca delta using digital Landsat

data, Remote Sensing of Environment, 11:9-14 